\title{
Effect of Varying Levels of Nitrogen and Planting Geometry on High Yielding Boro Rice in New Alluvial Zone of West Bengal
}

\author{
N. Kipgen ${ }^{1}$, Priyanka Irungbam ${ }^{2}$, S. Pal ${ }^{1}$, Meghna Gogoi ${ }^{2}$ and Yumnam Sanatombi ${ }^{2}$ \\ ${ }^{1}$ Department of Agronomy, Faculty of Agriculture, Bidhan Chandra Krishi Viswavidyalaya, \\ Mohanpur, West Bengal, 741252, India \\ ${ }^{2}$ Department of Agronomy, College of Agriculture, Central Agricultural University, \\ Iroishemba, 795004, India
}

*Corresponding author

\begin{abstract}
A B S T R A C T
\section{Keywords}

Boro rice, New alluvial zone,

Nitrogen level, Planting geometry, Shatabdi (IET 4786).

\section{Article Info}

Accepted:

15 June 2018

Available Online:

10 July 2018

A field experiment was conducted at Regional Research Sub Station (RRSS), New Alluvial Zone, Chakdah, Nadia, West Bengal during boro season (2013-2014) to study the effect of varying levels of nitrogen and planting geometry on high yielding boro rice. The experiment was laid out in factorial randomized block design (FRBD) replicated thrice. The treatments comprised of 4 nitrogen levels $\left(0,100,120\right.$ and $\left.140 \mathrm{~kg} \mathrm{~N} \mathrm{ha}^{-1}\right)$ and three planting geometry $(15 \mathrm{~cm} \mathrm{x} 15 \mathrm{~cm}, 20 \mathrm{~cm} \mathrm{x} 15 \mathrm{~cm}$ and $20 \mathrm{~cm} \mathrm{x} 20 \mathrm{~cm})$. The treatment receiving $140 \mathrm{~N} \mathrm{~kg} \mathrm{ha-1}$ gave the highest growth attributes such as plant height $(101.81 \mathrm{~cm})$, number of tiller $\mathrm{m}^{-2}$ (444.08) and dry matter accumulation (DMA) $(815.58 \mathrm{~g}$ $\mathrm{m}^{-2}$ ) which was statistically at par with $120 \mathrm{~N} \mathrm{~kg} \mathrm{ha}^{-1}$. Maximum plant height $(100.03 \mathrm{~cm})$ was obtained at $20 \mathrm{~cm} \times 20 \mathrm{~cm}$. However, maximum number of tillers hill ${ }^{-1}$ (473.62) and DMA $\left(847.33 \mathrm{~g} \mathrm{~m}^{-2}\right)$ were observed at $15 \mathrm{~cm} \mathrm{x} 15 \mathrm{~cm}$. Yield attributes like number of panicles $\mathrm{m}^{-2}$ (304.00), number of filled grains panicle ${ }^{-1}(124.52)$ and panicle length $(24.53$ $\mathrm{cm})$ were found maximum with nitrogen level of $120 \mathrm{~kg} \mathrm{ha}^{-1}$. Grain yield increased gradually with increasing level of nitrogen up to $120 \mathrm{~kg} \mathrm{~N} \mathrm{ha}^{-1}\left(4.54 \mathrm{t} \mathrm{ha}^{-1}\right)$ and the plant spacing of $20 \mathrm{~cm} \times 15 \mathrm{~cm}$ gave the highest grain yield $\left(4.16 \mathrm{t} \mathrm{ha}^{-1}\right)$.
\end{abstract}

\section{Introduction}

Rice (Oryza sativa) is an important cereal crop in the developing world and accounts for the dietary energy requirements for almost half of the world population. It is primarily a high energy or high caloric food containing around $78.2 \%$ carbohydrate, $6.8 \%$ protein, $0.5 \%$ fat and $0.6 \%$ mineral. At present, rice is cultivated in around 113 countries, which is a staple food for over half of the world's population (Prasad et al., 2012). Rice (Oryza sativa L.) is the principal crop of India cultivated in an area of 44 million ha annually with a production of $103 \mathrm{mt}$, with an average productivity of $2.3 \mathrm{t} / \mathrm{ha}$ (Parthipan et al., 2013). Boro rice accounts for the $26 \%$ of the gross rice growing areas of West Bengal and is grown under $100 \%$ irrigated condition with high yielding varieties mainly. It adds extra grain production for food security and brings about $48 \%$ increases in household income. 
The soil and climate of India in states like West Bengal, Assam and Orissa are favorable for rice cultivation throughout the year but the yield of this crop is much below the potential level. The reasons are manifolds; some are varietal, some are technical and some are socio-economic in nature. The potential for increasing rice production strongly depends on the ability to integrate a better crop management practices for the different varieties into existing cultivation systems (Mikkelsen et al., 1995). Proper management practices are the most effective means for increasing yield of boro rice. This will require the adoption of new technology such as best management package, high yielding cultivar, higher input use etc. Besides, a careful study of the whole situation reveals that a number of other factors are also responsible for the low yield of rice. Out of these, agronomic management practices such as spacing and nitrogen application are two major factors influencing the growth and yield of rice. Optimum dose of nitrogen fertilization plays a vital role in growth and development and grain formation as a result of higher yield of rice plant. Excessive nitrogen fertilization encourages excessive vegetative growth which makes the plant susceptible to insect, pest and diseases, which ultimately reduces yield whereas less than optimum rate affects both yield and quality of rice to remarkable extent. So, it is essential to find out the optimum rate of nitrogen application for efficient utilization of this element by the plants for better yield. Optimum plant spacing ensures plants to grow properly both in their aerial and underground parts through utilization of solar radiation and nutrients, therefore proper manipulation of planting density may lead to increase in the economic yield of transplanted rice (Sampath et al., 2017). Plant spacing determines the planting density or plant population in unit area thereby influencing the input use efficiency and yield of the crop. Spacing is a major non monetary input which plays a significant role in determining growth and yield of the crop. Keeping in view of the importance of optimum $\mathrm{N}$ supply to rice in relation to plant spacing for higher production, the present investigation was conducted to find out the optimum dose of nitrogen and spacing for boro rice variety Shatabdi (IET 4786).

\section{Materials and Methods}

Field experiment was conducted at Regional Research Sub-Station (RRSS), Chakdah, Nadia, New Alluvial Zone (NAZ) under Bidhan Chandra Krishi Viswavidyalaya, West Bengal at $23^{\circ} 5^{\prime} \mathrm{N}$ latitude and $83^{\circ} 5^{\prime} \mathrm{E}$ longitudes with an elevation of $9.75 \mathrm{~m}$ above the mean sea level. The soil of the experimental field was sandy clay loam in texture and belongs to the order Entisol. The experiment was conducted under irrigated shallow and medium land situation. The soil was medium in fertility with good drainage facility with $7.50 \mathrm{pH}, 0.68 \%$ organic carbon, $0.052 \%$ total nitrogen, $16.90 \mathrm{~kg} \mathrm{ha}^{-1}$ available phosphorus and $128.10 \mathrm{~kg} \mathrm{ha}^{-1}$ available potassium respectively. The experiment was laid out in a factorial randomized block design (FRBD) in 3 replications. The treatments comprised of 4 levels of nitrogen $(0,100,120$ and $140 \mathrm{~kg} \mathrm{~N} \mathrm{ha}^{-1}$ ) and three planting geometry $(15 \mathrm{~cm} \mathrm{x} 15 \mathrm{~cm}, 20 \mathrm{~cm} \mathrm{x} 15 \mathrm{~cm}$ and $20 \mathrm{~cm} \times 20 \mathrm{~cm})$. The cultivar used in the experiment was Shatabdi (IET 4786). Full dose of phosphorus and potassium in the form of single super phosphate (SSP) and muriate of potash (MOP) were applied as basal dose @ $60 \mathrm{~kg} \mathrm{ha}^{-1}$ each respectively at final land preparation. Nitrogen in the form of urea was applied in 3 split doses, each one as basal application and as top dressing at active tillering stage and at panicle initiation stage. 25 days old seedlings were transplanted at a desired spacing of $15 \mathrm{~cm} \mathrm{x} 15 \mathrm{~cm}, 20 \mathrm{~cm} \times 15$ $\mathrm{cm}$ and $20 \mathrm{~cm} \times 20 \mathrm{~cm}$ as per the treatments with 2-3 seedlings per hill at a depth of 3-4 
$\mathrm{cm}$. Irrigation was applied as and when required to maintain a shallow depth of submergence (3 to $5 \mathrm{~cm}$ ) beginning with planting and continuing up to 2 weeks before harvesting of the crop. To control weeds, two hand weeding were given at 21 days after transplanting (DAT) and at 42 DAT. Growth attributes were recorded at 30 days interval. Yield and yield attributes were recorded at harvest. The data so obtained were subjected to statistical analysis by the analysis of variance method (Panse and Sukhatme, 1978) and the significant of different sources of variations were tested by error mean square by Fisher and Snedecor's F test at probability level 0.05 .

\section{Results and Discussion}

\section{Growth attributes}

\section{Plant height (cm)}

The maximum plant height $(101.81 \mathrm{~cm})$ was recorded in treatment $\mathrm{N}_{3}$, receiving highest level of nitrogen of $140 \mathrm{~kg} \mathrm{ha}^{-1}$ but statistically at par with $\mathrm{N}_{2}(101.42 \mathrm{~cm})$ and $\mathrm{N}_{1}(100.26$ $\mathrm{cm})$ receiving $120 \mathrm{~kg}$ nitrogen $\mathrm{ha}^{-1}$ and $100 \mathrm{~kg}$ nitrogen $\mathrm{ha}^{-1}$ respectively where as lowest plant height $(86.44 \mathrm{~cm})$ was observed in control, $\mathrm{N}_{0}$. The increased in plant height with increasing nitrogen might be attributed to the effect of nitrogen fertilizer which encourage and improve plant growth and accelerate cell division which was reflected in the increased plant height (Mohadesi et al., 2011). Regarding the spacing, the maximum plant height $(100.03 \mathrm{~cm})$ was observed with wider spacing $\left(S_{3}\right)$ of $20 \mathrm{~cm} \times 20 \mathrm{~cm}$ followed by $S_{2}$ i.e. $20 \mathrm{~cm} \times 15 \mathrm{~cm}(97.14 \mathrm{~cm})$ but with no significant difference between them. The interaction effect did not show any significant difference although $\mathrm{N}_{3} \mathrm{~S}_{3}$ recorded the maximum plant height $(102.93 \mathrm{~cm})$ whereas lowest plant height $(80.0 \mathrm{~cm})$ was recorded by $\mathrm{N}_{0} \mathrm{~S}_{1}$ (Table 1). Maximum plant height was obtained with wider planting geometry $\left(\mathrm{S}_{3}\right)$ as compared to closer spacing of $S_{2}$ and $S_{1}$ because of creation of an optimum condition for light reception, water and nutrient consumption and less competition. This result is at par with the findings of Haque (2002) and Sridhara (2008).

\section{Number of tillers $\mathrm{m}^{-2}$}

The maximum number of tillers $\mathrm{m}^{-2}$ (444.08) was recorded in treatment receiving highest dose of nitrogen $\left(\mathrm{N}_{3}\right)$ but statistically at par with $\mathrm{N}_{2}$ (441.13) and lowest (234.44) was obtained in control, $\mathrm{N}_{0}$. This was mainly due to more nitrogen availability at higher levels of nitrogen that provided proper nutrition to the crop thereby increased tillering. Higher dose of nitrogen might have helped in inducing vegetative growth leading to better interception of photosynthetically active radiation and greater photosynthesis by the crop. (Anil et al., 2018). Among the three spacing, the maximum number of tillers $\mathrm{m}^{-2}$ (473.62) was attained in close spacing $\left(S_{1}\right)$ followed by $S_{2}$ (381.29) which might be due to more number of hills per unit area (Table 1). These results are in line with those reported by Banerjee and Pal (2011) and Haque et al., (2015). Among the interaction effects, $\mathrm{N}_{3} \mathrm{~S}_{1}$ recorded maximum number of tillers $\mathrm{m}^{-2}$ (545.60) but was statistically at par with $\mathrm{N}_{1} \mathrm{~S}_{1}$ (532.40) and $\mathrm{N}_{2} \mathrm{~S}_{1}$ (541.93). The lowest number of tillers $\mathrm{m}^{-2}$ (195.00) was obtained in $\mathrm{N}_{0} \mathrm{~S}_{3}$ which was lower than other interaction effects.

\section{Dry matter accumulation/DMA $\left(\mathrm{g} \mathrm{m}^{-2}\right)$}

Similarly, $\mathrm{N}_{3}$ recorded highest dry matter accumulation $\left(815.58 \mathrm{~g} \mathrm{~m}^{-2}\right)$ followed by $\mathrm{N}_{2}$ $\left(807.51 \mathrm{~g} \mathrm{~m}^{-2}\right)$ and $\mathrm{N}_{1}\left(783.81 \mathrm{~g} \mathrm{~m}^{-2}\right)$ but were statistically at par with each other. The higher total dry matter production was attributed to better plant growth which resulted in higher dry matter accumulation in leaves and stem at 
early growth stages and better translocation to ear heads during later stages (Prakasha et al., 2018). Significant differences were noticed among the different spacing i.e. $S_{1}, S_{2}$ and $S_{3}$ with respect to dry matter accumulation where close spacing of $15 \mathrm{~cm} \times 15 \mathrm{~cm}\left(\mathrm{~S}_{1}\right)$ recorded highest dry matter $\left(847.33 \mathrm{~g} \mathrm{~m}^{-2}\right)$ followed by wider spacing, $\mathrm{S}_{2}\left(738.38 \mathrm{~g} \mathrm{~m}^{-2}\right)$ and $\mathrm{S}_{3}$ $\left(635.86 \mathrm{~g} \mathrm{~m}^{-2}\right)$ respectively. The $\mathrm{N}_{3} \mathrm{~S}_{1}$ interaction recorded the highest dry matter accumulation $\left(930.21 \mathrm{~g} \mathrm{~m}^{-2}\right)$ whereas the interaction $\mathrm{N}_{0} \mathrm{~S}_{3}$ recorded the lowest (478.67 $\mathrm{g}$ $\mathrm{m}^{-2}$ ) but there was no significant difference among the various interactions (Table 1). Close spacing recorded higher dry matter accumulation due to accommodation of more number of plants $\mathrm{m}^{-2}$. Similar observation was also recorded by Mohadesi et al., (2011).

\section{Yield attributes}

\section{Number of panicles $\mathbf{m}^{-2}$}

Number of panicle $\mathrm{m}^{-2}$ significantly varied with varying levels of nitrogen. Maximum number of panicle $\mathrm{m}^{-2}$ was recorded with $\mathrm{N}_{2}$ (304.00) followed by $\mathrm{N}_{3}$ (303.18), $\mathrm{N}_{1}$ (289.11) and lowest (159.75) was recorded in control $\left(\mathrm{N}_{0}\right)$ (Table 2). Mandal et al., (1986) and Mahato et al., (2007) too reported that higher levels of $\mathrm{N}$ application increased the number of panicles $\mathrm{m}^{-2}$ and thereafter decreased with fertilizers. Excessive nitrogen application decreased the effective number of panicles and grains per panicle and then eventually reduced rice production (Zhu et al., 2017). Closer spacing of $15 \mathrm{~cm} \mathrm{x} 15 \mathrm{~cm}\left(\mathrm{~S}_{1}\right)$ recorded significantly higher number of panicles $\mathrm{m}^{-2}$ (293.37) than wider spacing, $S_{2}$ (261.22) and $\mathrm{S}_{3}$ (237.44) respectively. This might be due to higher plant population per unit area at close spacing. Mahato et al., (2007) reported similar type of variation where closer spacing gave highest number of panicles $\mathrm{m}^{-2}$. Interaction of nitrogen levels and planting geometry showed significant influence on number panicles per $\mathrm{m}^{-2} \cdot \mathrm{N}_{2} \mathrm{~S}_{1}$ interaction recorded the maximum number of panicles $\mathrm{m}^{-2}$ (339.26) which was at par with $\mathrm{N}_{3} \mathrm{~S}_{1}$ (338.22) whereas, the interaction $\mathrm{N}_{0} \mathrm{~S}_{3}$ recorded the lowest panicles $\mathrm{m}^{-2}$ (150.83).

\section{Number of filled grains panicle ${ }^{-1}$}

The highest number of filled grains panicle ${ }^{-1}$ (124.52) was obtained at $120 \mathrm{~kg} \mathrm{~N} \mathrm{ha}^{-1}\left(\mathrm{~N}_{2}\right)$ which was statistically at par with $\mathrm{N}_{3}$ (123.89) followed by $\mathrm{N}_{1}$ (123.04). The lowest number of filled grains panicle ${ }^{-1}$ (81.44) was obtained from $\mathrm{N}_{0}$ (Table 2). Nitrogen helps in proper filling of seeds which resulted in higher production of seeds and thus higher number of filled grains panicle ${ }^{-1}$. More number of filled grains panicle ${ }^{-1}$ (115.29) were noted with 20 $\mathrm{cm}$ × $20 \mathrm{~cm}\left(\mathrm{~S}_{3}\right)$ plant spacing followed by closer spacing $S_{2}$ (113.34) and $S_{1}$ (111.03). This might be due to supply of more food materials, moisture and light for the plant under wider spacing and ultimately resulted in better environment for growth and development of the crop (Uddin et al., 2011). The maximum number of filled grains panicle 1 (127.27) was obtained in the treatment combination of $120 \mathrm{~kg} \mathrm{~N}^{-1}$ and spacing 20 $\mathrm{cm}$ x $20 \mathrm{~cm}\left(\mathrm{~N}_{2} \mathrm{~S}_{3}\right)$ which was at par with $\mathrm{N}_{2} \mathrm{~S}_{3}$ (126.17).

\section{Panicle length (cm)}

Panicle length significantly increased with the increase of nitrogen rate up to $120 \mathrm{~kg} \mathrm{~N} \mathrm{ha}^{-1}$ and thereafter declined. Panicle length was highest in $\mathrm{N}_{2}(24.53 \mathrm{~cm})$ but was statistically at par with $\mathrm{N}_{3}(24.41 \mathrm{~cm})$ and $\mathrm{N}_{1}(24.01 \mathrm{~cm})$. Nitrogen takes part in panicle formation as well as panicle elongation and for this reason, panicle length increased with the increase of nitrogen fertilization up to $120 \mathrm{~kg} \mathrm{ha}^{-1}$. Plant spacing also had significant effect on panicle length. Longest panicle $(24.21 \mathrm{~cm})$ was observed with $20 \mathrm{~cm} \times 20 \mathrm{~cm}$ spacing $\left(\mathrm{S}_{3}\right)$ but was statistically at par with $20 \mathrm{~cm} \times 15 \mathrm{~cm}$ 
$\left(\mathrm{S}_{2}\right)$ with $23.83 \mathrm{~cm}$ followed by $\mathrm{S}_{1}(23.04 \mathrm{~cm})$. The longest panicle $(25.04 \mathrm{~cm})$ was obtained from $20 \mathrm{~cm}$ x $20 \mathrm{~cm}$ with $120 \mathrm{~kg} \mathrm{~N} \mathrm{ha}^{-1}\left(\mathrm{~N}_{2} \mathrm{~S}_{3}\right)$ which was higher than all other interaction effects. Plants grown at any plant spacing without $\mathrm{N}$ fertilizer produced shortest panicle (Table 2).

\section{Panicle weight (g)}

Varied level of nitrogen significantly differed the panicle weight and it ranges from $1.49 \mathrm{~g}$ to $2.06 \mathrm{~g}$. Maximum panicle weight (2.06 g) was observed with the application of nitrogen 120 $\mathrm{kg} \mathrm{ha}^{-1}\left(\mathrm{~N}_{2}\right)$ but was statistically at par with $\mathrm{N}_{3}$ $(2.03 \mathrm{~g})$ followed by $\mathrm{N}_{1}(1.92 \mathrm{~g})$. The increase in yield-attributing characters of aerobic rice with the increase in $\mathrm{N}$ application might be owing to higher availability of $\mathrm{N}$ to plants leading to its higher uptake and translocation from vegetative parts to reproductive parts resulting in increased yield attributes (Nayak et al., 2016). Wider spacing $\mathrm{S}_{3}$ show significantly higher panicle weight $(1.92 \mathrm{~g})$ followed by $\mathrm{S}_{2}(1.89 \mathrm{~g})$ and least weight was obtained in close spacing, $S_{1}(1.81 \mathrm{~g})$. This might be due to competition of plants for light within the dense plants at closer hill spacing resulting in reduced panicle weight due to reduction in the rate of photosynthesis (Yadav, 2007). There was no significant difference among the interactions. However, wider spacing in combination with $120 \mathrm{~kg} \mathrm{~N} \mathrm{ha}{ }^{-1}$ recorded highest panicle weight $(2.12 \mathrm{~g})$ followed by $\mathrm{N}_{2} \mathrm{~S}_{2}$ and $\mathrm{N}_{3} \mathrm{~S}_{3}$ with a value of $2.08 \mathrm{~g}$ (Table 3).

Table.1 Effect of nitrogen and planting geometry on plant height $(\mathrm{cm})$, number of tiller $\mathrm{m}^{-2}$ and dry matter accumulation of boro rice

\begin{tabular}{|c|c|c|c|c|c|c|c|c|c|c|c|c|}
\hline \multirow[t]{2}{*}{ Treatment } & \multicolumn{4}{|c|}{ Plant height (cm) } & \multicolumn{4}{|c|}{ Number of tillers $\mathbf{m}^{-2}$} & \multicolumn{4}{|c|}{ Dry matter accumulation $\left(\mathrm{g} \mathrm{m}^{-2}\right)$} \\
\hline & $\mathrm{S}_{1}$ & $\mathrm{~S}_{2}$ & $\mathrm{~S}_{3}$ & Mean & $\mathrm{S}_{1}$ & $\mathrm{~S}_{2}$ & $\mathrm{~S}_{3}$ & Mean & $\mathrm{S}_{1}$ & $\mathrm{~S}_{2}$ & $\mathrm{~S}_{3}$ & Mean \\
\hline $\mathbf{N}_{0}$ & 80.00 & 85.33 & 94.00 & 86.44 & 274.56 & 233.75 & 195.00 & 234.44 & 620.40 & 566.50 & 478.67 & 555.19 \\
\hline $\mathbf{N}_{1}$ & 99.33 & 100.37 & 101.07 & 100.26 & 532.40 & 423.28 & 334.33 & 430.00 & 912.76 & 770.00 & 668.67 & 783.81 \\
\hline $\mathbf{N}_{2}$ & 100.70 & 101.43 & 102.13 & 101.42 & 541.93 & 432.30 & 349.17 & 441.13 & 925.96 & 806.30 & 690.28 & 807.51 \\
\hline $\mathbf{N}_{3}$ & 101.07 & 101.43 & 102.93 & 101.81 & 545.60 & 435.82 & 350.83 & 444.08 & 930.21 & 810.70 & 705.83 & 815.58 \\
\hline \multirow[t]{2}{*}{ Mean } & 95.28 & 97.14 & 100.03 & 97.48 & 473.62 & 381.29 & 307.33 & 387.41 & 847.33 & 738.38 & 635.86 & 740.52 \\
\hline & $\mathrm{N}$ & $\mathrm{S}$ & & X S & $\mathrm{N}$ & $S$ & & X S & $\mathrm{N}$ & S & & X S \\
\hline $\operatorname{SEm}( \pm)$ & 1.486 & 1.287 & & 574 & 4.103 & 3.55 & & 106 & 12.615 & 10.9 & & 1.850 \\
\hline $\begin{array}{l}\text { CD } \\
(p=0.05)\end{array}$ & 4.358 & 3.774 & & & 12.032 & 10.4 & & 0.841 & 36.998 & 32.0 & & \\
\hline
\end{tabular}

$\mathrm{N}_{0}$ : Control, $\mathrm{N}_{1}: 100 \mathrm{~kg} \mathrm{ha}^{-1}, \mathrm{~N}_{2}: 120 \mathrm{~kg} \mathrm{ha}^{-1}, \mathrm{~N}_{3}: 140 \mathrm{~kg} \mathrm{ha}^{-1}$

$\mathrm{S}_{1}: 15 \mathrm{~cm}$ x $15 \mathrm{~cm}, \mathrm{~S}_{2}: 20 \mathrm{~cm}$ x $15 \mathrm{~cm}, \mathrm{~S}_{3}: 20 \mathrm{~cm} \mathrm{x} 20 \mathrm{~cm}$ 
Table.2 Effect of nitrogen and planting geometry on number of panicles $\mathrm{m}^{-2}$, number of filled grains panicle ${ }^{-1}$ and panicle length of boro rice

\begin{tabular}{|c|c|c|c|c|c|c|c|c|c|c|c|c|}
\hline \multirow[t]{2}{*}{ Treatment } & \multicolumn{4}{|c|}{ Number of panicles $\mathrm{m}^{-2}$} & \multicolumn{4}{|c|}{ Number of filled grains panicle ${ }^{-1}$} & \multicolumn{4}{|c|}{ Panicle length $(\mathrm{cm})$} \\
\hline & $\mathrm{S}_{1}$ & $\mathrm{~S}_{2}$ & $\mathrm{~S}_{3}$ & Mean & $\mathrm{S}_{1}$ & $\mathrm{~S}_{2}$ & $\mathrm{~S}_{3}$ & Mean & $\mathrm{S}_{1}$ & $\mathrm{~S}_{2}$ & $\mathrm{~S}_{3}$ & Mean \\
\hline $\mathrm{N}_{0}$ & 172.30 & 156.11 & 150.83 & 159.75 & 80.04 & 81.74 & 82.53 & 81.44 & 21.00 & 22.03 & 22.41 & 21.81 \\
\hline $\mathrm{N}_{1}$ & 323.70 & 287.22 & 256.42 & 289.11 & 120.57 & 123.35 & 125.21 & 123.04 & 23.50 & 24.07 & 24.47 & 24.01 \\
\hline $\mathrm{N}_{2}$ & 339.26 & 301.33 & 271.42 & 304.00 & 122.09 & 124.19 & 127.27 & 124.52 & 23.93 & 24.61 & 25.04 & 24.53 \\
\hline $\mathrm{N}_{3}$ & 338.22 & 300.22 & 271.08 & 303.18 & 121.41 & 124.07 & 126.17 & 123.89 & 23.71 & 24.60 & 24.93 & 24.41 \\
\hline \multirow[t]{2}{*}{ Mean } & 293.37 & 261.22 & 237.44 & 264.01 & 111.03 & 113.34 & 115.29 & 113.22 & 23.04 & 23.83 & 24.21 & 23.69 \\
\hline & $\mathrm{N}$ & \multicolumn{2}{|l|}{ S } & NX S & $\mathrm{N}$ & \multicolumn{2}{|l|}{ S } & NX S & $\mathrm{N}$ & \multicolumn{2}{|l|}{$\mathrm{S}$} & NX S \\
\hline $\operatorname{SEm}( \pm)$ & 3.245 & \multicolumn{2}{|c|}{2.810} & 5.620 & 0.221 & \multicolumn{2}{|c|}{0.191} & 0.383 & 0.288 & \multicolumn{2}{|c|}{0.249} & 0.498 \\
\hline $\begin{array}{l}\mathrm{CD} \\
(\mathrm{p}=0.05)\end{array}$ & 9.516 & \multicolumn{2}{|c|}{8.241} & 16.482 & 0.648 & \multicolumn{2}{|c|}{0.561} & 1.123 & 0.844 & \multicolumn{2}{|c|}{0.731} & NS \\
\hline
\end{tabular}

Table.3 Effect of nitrogen and planting geometry on panicle weight, grain yield and straw yield of boro rice

\begin{tabular}{|c|c|c|c|c|c|c|c|c|c|c|c|c|}
\hline \multirow[t]{2}{*}{ Treatment } & \multicolumn{4}{|c|}{ Panicle weight (g) } & \multicolumn{4}{|c|}{ Grain yield $\left(\mathrm{t} \mathrm{ha}^{-1}\right)$} & \multicolumn{4}{|c|}{ Straw yield $\left(\mathrm{t} \mathrm{ha}^{-1}\right)$} \\
\hline & $\mathrm{S}_{1}$ & $\mathrm{~S}_{2}$ & $\mathrm{~S}_{3}$ & Mean & $\mathrm{S}_{1}$ & $\mathrm{~S}_{2}$ & $\mathrm{~S}_{3}$ & Mean & $\mathrm{S}_{1}$ & $\mathrm{~S}_{2}$ & $\mathrm{~S}_{3}$ & Mean \\
\hline $\mathrm{N}_{0}$ & 1.35 & 1.55 & 1.57 & 1.49 & 2.67 & 2.75 & 2.83 & 2.75 & 3.78 & 3.84 & 3.93 & 3.85 \\
\hline $\mathrm{N}_{1}$ & 1.93 & 1.93 & 1.91 & 1.92 & 4.20 & 4.52 & 4.10 & 4.27 & 5.37 & 5.58 & 5.30 & 5.42 \\
\hline $\mathrm{N}_{2}$ & 1.99 & 2.08 & 2.12 & 2.06 & 4.45 & 4.87 & 4.30 & 4.54 & 5.59 & 5.93 & 5.48 & 5.67 \\
\hline $\mathrm{N}_{3}$ & 1.99 & 2.01 & 2.08 & 2.03 & 4.33 & 4.49 & 4.17 & 4.33 & 5.53 & 5.58 & 5.39 & 5.50 \\
\hline \multirow[t]{2}{*}{ Mean } & 1.81 & 1.89 & 2.01 & 1.88 & 3.91 & 4.16 & 3.85 & 3.97 & 5.07 & 5.23 & 5.03 & 5.11 \\
\hline & $\mathrm{N}$ & \multicolumn{2}{|l|}{ S } & NXS & $\mathrm{N}$ & \multicolumn{2}{|l|}{ S } & NX S & $\mathrm{N}$ & \multicolumn{2}{|c|}{ S } & NX S \\
\hline $\operatorname{SEm}( \pm)$ & 0.031 & \multicolumn{2}{|c|}{0.027} & 0.054 & 0.096 & \multicolumn{2}{|c|}{0.083} & 0.166 & 0.068 & \multicolumn{2}{|c|}{0.059} & 0.118 \\
\hline $\begin{array}{l}\mathrm{CD} \\
(\mathrm{p}=0.05)\end{array}$ & 0.091 & \multicolumn{2}{|c|}{0.079} & NS & 0.281 & \multicolumn{2}{|c|}{0.243} & NS & 0.199 & \multicolumn{2}{|c|}{0.173} & NS \\
\hline
\end{tabular}




\section{Yield $\left(\mathrm{t} \mathrm{ha}^{-1}\right)$}

The highest grain yield $\left(4.54 \mathrm{t} \mathrm{ha}^{-1}\right)$ was obtained with $120 \mathrm{~kg} \mathrm{~N}^{-1}$ i.e. $\mathrm{N}_{2}$ which was statistically at par with $\mathrm{N}_{1}\left(4.27 \mathrm{t} \mathrm{ha}^{-1}\right)$ and $\mathrm{N}_{3}$ $\left(4.33 \mathrm{t} \mathrm{ha}^{-1}\right)$. It is due to better nutrient uptake leading to higher dry matter production and its translocation to sink leading to increased percent of filled grains and number of panicles $\mathrm{m}^{-2}$ (Mandal et al., 1986). Closer spacing of $20 \mathrm{~cm} \quad x \quad 15 \mathrm{~cm}$ produced significantly higher grain yield $\left(4.16 \mathrm{tha}^{-1}\right)$ as compared to wider spacing $20 \mathrm{~cm} \times 20 \mathrm{~cm}$ $\left(3.85 \mathrm{t} \mathrm{ha}^{-1}\right)$. Very close spacing $\mathrm{S}_{1}(15 \mathrm{~cm} \mathrm{x}$ $15 \mathrm{~cm})$ was undesirable for economic yield (Table 3). Further Wells and Faw (1978) reported that close spacing decrease light interception and $\mathrm{CO}_{2}$ assimilation which in turn limit the rice yield. Namba (2003) reported that the increase in grain yield with optimum plant spacing might be attributed to increased number of tillers per unit area and filled grains per panicle after which plant growth slows down if it exceed the optimum level. Straw yield increased significantly up to $120 \mathrm{~kg} \mathrm{~N} \mathrm{ha}{ }^{-1}$, thereafter decreased with increase in the nitrogen level.

Maximum straw yield (5.67 $\left.\mathrm{t} \mathrm{ha}^{-1}\right)$ was recorded with $120 \mathrm{~kg} \mathrm{ha}^{-1}$ nitrogen $\left(\mathrm{N}_{2}\right)$ but was statistically at par with $\mathrm{N}_{3}\left(5.50 \mathrm{t} \mathrm{ha}^{-1}\right)$ followed by $\mathrm{N}_{1}\left(5.42 \mathrm{t} \mathrm{ha}^{-1}\right)$. This might be due to vigorous growth with increase in $\mathrm{N}$ level resulted in higher straw yield (Chopra and Chopra, 2004). Planting density greatly influenced the straw yield. The plant spacing of $20 \mathrm{~cm} \times 15 \mathrm{~cm}\left(\mathrm{~S}_{2}\right)$ recorded highest straw yield $\left(5.23 \mathrm{t} \mathrm{ha}^{-1}\right)$ as compared to closer spacing $\mathrm{S}_{1}\left(5.07 \mathrm{t} \mathrm{ha}^{-1}\right)$ and wider spacing $\mathrm{S}_{3}$ (5.07 $\mathrm{t} \mathrm{ha}^{-1}$ ) which might be due to reduce plant height and lesser plant population respectively. Similar observation was reported by Mahato et al., (2006). However, the interaction effects were not significant. The increase in yield of hybrid rice due to $\mathrm{N}$ fertilization was attributed directly by the significant improvement of all the yield attributing traits viz. effective tiller $\mathrm{m}^{-2}$, panicle length, filled grains panicle ${ }^{-1}$ and test weight (Banerjee and Pal, 2011).

Therefore, it can be concluded that treatment combination of $120 \mathrm{~kg}$ nitrogen $\mathrm{ha}^{-1}$ along with planting geometry of $20 \mathrm{~cm} \mathrm{x} 15 \mathrm{~cm}$ could be recommended for cultivation of boro rice in New Alluvial Zone of West Bengal.

\section{Acknowledgement}

The authors are thankful to Bidhan Chandra Krishi Vishwavidalaya, Nadia, West Bengal for providing the field and necessary lab facilities for conducting this research.

\section{References}

Anil, K., Yakadri, M and Jayasree, G. 2018. Influence of nitrogen levels and times of application on growth parameters of aerobic rice. Int.J.Curr.Microbiol. App.Sci. 7(5): 1525-1529.

Banerjee, $\mathrm{H}$ and Pal, S. 2011. Effect of planting geometry and different levels of nitrogen on hybrid rice. Oryza, 48 (3): 274-275.

Chopra, N.K. and Chopra, N. 2004. Seed yield and quality of 'Pusa44' rice as influenced by nitrogen fertilizer and row spacing. Indian Journal Agricultural Sciences. 74 (3): 144146.

Haque, D. E. 2002. Effect of Madagascar technique of younger seedling and wider spacing on growth and yield of boro rice. M.Sc. Thesis, Department of Agronomy, BAU, Mymensingh. pp. 50-80.

Haque, M. A., Razzaque, A. H. M., Haque, A. N. A. and Ullah, M. A. 2015. Effect of plant spacing and nitrogen on yield of transplant aman rice var. BRRI Dhan 52. Journal of Bioscience and 
Agriculture Research. 04 (02): 52-59.

Mahato. P., Gunri. S. K., Chanda. K. and Ghosh.M. 2007. Effect of varying Levels of Fertilizer and Spacing on Medium Duration Rice (Oryza Sativa L.) in Tarai Zone of West Bengal. Karnataka Journal Agricultural Science. 20(2): (363-365).

Mandal, S. S., Das Mahapatra, A. N. and Chatterjee, B. N. 1986. Effect of highrates of Potassium and Nitrogen on rice yield components. Environment and Ecology. 5: 300-303.

Mikkelsen, D. S., Jayaweera, G. R. and Rolston, D. E. 1995. Nitrogen fertilization practices of low land rice culture. Nitrogen Fertilization in the Environment. 171-223.

Mohadesi, A., Abbasian, A., Bakhshipour, S. and Aminpanah, H. 2011. Effect of different level of nitrogen and plant spacing on yield, yield components and physiological indices in Highyield Rice. American- Eurasian journal agriculture and environmental science.10 (5):893-900.

Namba, T. 2003. Optimum planting density and nitrogen application rate for maximizing rice yield. Crop Science Society of Japan. Japanese Journal of Crop Science. 72(2): 133-141.

Nayak, B.R., Pramanik, K., Khanda, C.M., Panigrahy, N., Samant, P.K., Mohapatra, S., Mohanty, A.K., Dash, A.K., Panda, N. and Swain, S.K. 2016. Response of aerobic rice (Oryza sativa) to different irrigation regimes and nitrogen levels in western Odisha. Indian Journal of Agronomy. 61 (3): 321-325.

Panse, V.G and Sukhatme, P.V. 1978. Statistical Methods for Agricultural Workers. Edn 2. 197 pp. Indian Councial of Agricultural Research, New Delhi.

Parthipan T, Ravi V, Subramanian E and
Ramesh T. 2013. Integrated weed management on growth and yield of transplanted rice and its residual effect on succeeding black gram. Journal of Agronomy. 12 (2): 99-103.

Prakasha, G., Kalyana Murthy, K.N., Prathima, A.S. and Meti, R.N. 2018. Effect of Spacing and Nutrient Levels on Growth Attributes and Yield of Finger Millet (Eleusine coracana L. Gaertn) Cultivated under Guni Planting Method in Red Sandy Loamy Soil of Karnataka, India. Int.J.Curr.Microbiol.App.Sci. 7(5): 1337-1343.

Prasad, S. R., Rao, L. V. and Udaya Bhaskar, K. 2012. Hybrid rice seed production scenario in India. "6th international hybrid rice symposium", Hyderabad, India.

Sampath, O., Srinivas, A., Avil Kumar, K. and Ramprakash, T. 2017. Effect of plant density and fertilizer levels on growth parameters of rice varieties under late sown conditions. Int. Journal of Agri. Sci. and Res. 7 (3): 375-384.

Sridhara, C. J., 2008. Effect of genotypes, planting geometry and methods of establishment and micronutrient application on growth and of aerobic rice. Ph.D., Thesis University of Agricultural Sciences., Bangalore.

Uddin, M. A., Ali, M. H., Biswas, P. K., Masum, S. M.and Mandal, M. S. H. 2013. Influence of nitrogen and plant spacing on the yield of boro rice. Experiment Bioscience. 4(2):35-38.

Uddin, M.J., Ahmed, S., Rashi, M.H., Hasan, M.M and Asaduzzaman, M. 2011. Effect of spacing on the yield and yield attributes of transplanted aman rice cultivars in medium lowland ecosystem of Bangladesh. Journal of Agricultural Research. 49 (4): 465476. 
Wells, B. R. and Faw. 1978. Short statured rice response to seedlings and nitrogen rates. Agronomy Journal. 70: 477-478.

Yadav, V.K. 2007. Studies on the effect of dates of planting, plant geometry and number of seedlings per hill in hybrid rice (Oryza sativa L.) Ph D Thesis. Chandra Shekhar Azad University of Agriculture and Technology, Kanpur.
208002 (U.P.) India.

Zhu Da-wei, Zhang Hong-cheng, Guo Baowei, Xu Ke, Dai Qi-gen, Wei Hai-yan, Gao Hui, Hu Ya-jie, Cui Pei-yuan, Huo Zhong-yang. 2017. Effects of nitrogen level on yield and quality of japonica soft super rice. Journal of Integrative Agriculture. 16 (5): 10181027.

\section{How to cite this article:}

Kipgen, N., Priyanka Irungbam, S. Pal, Meghna Gogoi and Yumnam Sanatombi. 2018. Effect of Varying Levels of Nitrogen and Planting Geometry on High Yielding Boro Rice in New Alluvial Zone of West Bengal. Int.J.Curr.Microbiol.App.Sci. 7(07): 2090-2098. doi: https://doi.org/10.20546/ijcmas.2018.707.246 